\title{
THE SHARED MANAGEMENT OF TRANSBOUNDARY WATERS, BRAZIL AND COLOMBIA
}

\author{
a gestão compartilhada de águas transfronteiriças, Brasil e Colômbia
}

\author{
Christian Ricardo Ribeiro * \\ Oscar Buitrago Bermúdez ** \\ Antonio Cezar Leal ***
}

\begin{abstract}
If in the internal area of the States the complexity that wraps the rational use of the waters is enormous, in the actions of international nature the formulation of rules becomes necessary to make possible the harmonious conciliation of particular interests of the involved States. This study aims to analyze the management of transboundary waters of Brazil and Colombia, countries that stand out for their significant water availability and because they share the waters of the Amazon Basin. For this proposal, we intend to analyze the legal framework and institutional arrangements of water resource management specific to these countries, trying to recognize the consistencies and divergences, as well as the challenges and possible improvements in the sustainable management of transboundary waters of Brazil and Colombia, even taking into account the path followed by the two countries regarding the issue, especially around the Amazon Cooperation Treaty.
\end{abstract}

Key words: Transboundary waters; Amazon Basin; shared management

\section{Resumo}

A complexidade que envolve o uso racional das águas nas ações de natureza internacional torna indispensável o estabelecimento de regras norteadoras que possibilitem a conciliação harmoniosa dos interesses particulares dos Estados envolvidos. Assim, este trabalho se propõe a analisar o gerenciamento das águas transfronteiriças de Brasil e Colômbia, países que se destacam por sua significativa disponibilidade hídrica e por compartilharem águas da Bacia Hidrográfica Amazônica. Para tanto, analisa-se o arcabouço legal e o arranjo institucional da gestão de recursos hídricos específicos destes países, buscando-se reconhecer as congruências e divergências existentes, bem como os possíveis avanços e desafios para o gerenciamento sustentável das águas transfronteiriças de Brasil e Colômbia, inclusive levando-se em conta a trajetória já percorrida por esses países no que tange à questão, destacando-se aí o Tratado de Cooperação Amazônica.

Palavras-chave: Águas transfronteiriças; Bacia Amazônica; Gestão compartilhada.

\section{Resumen}

Si en el ámbito interno de los Estados la complejidad que envuelve el uso racional de las aguas es grande, en las acciones de naturaleza internacional será indispensable el establecimiento de reglas orientadoras que posibiliten la conciliación armoniosa de los intereses particulares de los Estados involucrados. Así, este trabajo se propone analizar la gestión de las aguas transfronterizas compartidas por Colombia y Brasil, países que destacan por su significativa disponibilidad hídrica y por compartir aguas de la cuenca hidrográfica Amazónica. Para ello, se analiza la estructura legal e institucional de la gestión de los recursos hídricos específicos de estos países, buscando reconocer las congruencias y divergencias existentes, así como los posibles avances y desafíos para la gestión sustentable de las aguas transfronterizas de Brasil y Colombia, inclusive teniendo en cuenta la trayectoria ya realizada por esos países en lo que tiene que ver con el tema, destacándose el Tratado de Cooperación Amazónica.

Palabras-clave: Aguas transfronterizas; Cuenca Amazónica; Gestión compartida.

(*) Master in Geography from Universidade Estadual Paulista - Avenida Eugênio do Nascimento, s/n. ${ }^{\circ}$ Juiz de Fora (MG), Brazil. Zip Code: 36038-330. Phone: (+55 32) 3239-3700 - christianric@hotmail.com

(**) Professor Ph. D. of Universidad del Valle - Ciudad Universitaria, Calle 13 \# 100 - 00, Edificio 38 - Departamento de Geografía, Cali, Colombia. Phone: (572) 3212189 - osbube@yahoo.com

(***) Research Productivity Scholar from CNPq - Level 2, Professor Ph.D. of Universidade Estadual Paulista, Presidente Prudente - Rua Roberto Simonsen, 305 - Presidente Prudente (SP), Brazil, Zip Code: 19060-900, Phone: (+55 32) $3229-5855$ - cezar@fct.unesp.br 


\section{INTRODUCTION}

The big problem regarding water scarcity in a large part of the world is related, among other factors, to the unequal distribution of water resources with regards to population concentration. In this sense, Latin America stands out; a privileged subcontinent in terms of water availability, but not exempt of problems associated with water resources management in the planet. Latin America is the region that experiences the most comfortable relation between water availability (in 1000 m3) and number of inhabitants in the world. South America stands for $6 \%$ of the global population and $26 \%$ of the global water availability (UNESCO, 2004).

South America also includes some of the richest countries in water reserves of the entire planet. Among them, Brazil ranked first place worldwide in terms of rivers discharge $(6220 \mathrm{~km} 3 /$ year $)$, and Colombia ranked eight place worldwide regarding this (1200 km3/year). In addition, both are classified as water rich countries (between 10000 and $100000 \mathrm{~m} 3 /$ inhab./year) and as low-use level (between 100 and $500 \mathrm{~m} 3 /$ inhab./year) (MARGAT, 1998). The attention of this research is set upon these two countries.

Brazil, a country of continental dimensions and with a great diversity of biomes, has a territory of 8,514,876.599 km2 and a population of 190,732,694 inhabitants, according to Demographic Census of 2010 of Instituto Brasileiro de Geografia e Estatística [The Brazilian Institute of Geography and Statistics] (IBGE). The predominantly humid climate in great part of the country provides the maintenance of a dense hydrographic network constituted by rivers of high volume of water. The country stands out in the global scenario because of fresh water discharge of its rivers, whose water production is $177900 \mathrm{~m} 3 / \mathrm{sec}$. When added to the $73100 \mathrm{~m} 3 / \mathrm{sec}$ of the remaining Amazon Basin in other countries, it represents $53 \%$ of the fresh water production in the South-American continent $(334000 \mathrm{~m} 3 / \mathrm{sec})$ and $12 \%$ of the worldwide total $(1,488,000 \mathrm{~m} 3 / \mathrm{sec})(\mathrm{COSTA}, 2007, \mathrm{p} .06)$.

Colombia, strategically placed in the center of American continent, has a territory of $1,141,748$ $\mathrm{km} 2$ and a population of 45,508,205 inhabitants, according to data of Demographic Census of 2005 of Departamento Administrativo Nacional de Estadísticas (DANE). Due to its geographic location and its terrain conditions, it accounts with an yearly mean precipitation close to $3000 \mathrm{~mm}$, much greater than the world's mean of $900 \mathrm{~mm}$ and to the $1600 \mathrm{~mm}$ of South America's mean. Such precipitation equals to the yearly water volume of $3425 \mathrm{~km} 3$, of which $61 \%$ converts to runoff, generating a yearly volume of $2113 \mathrm{~km} 3$, with outflows that range between 1 to $100 \mathrm{l} / \mathrm{sec} / \mathrm{km} 2$. Only $40 \%$ of the water offer are necessary to maintain the ecosystems and preserve them (MINISTERIO DO MEIO AMBIENTE, 2003).

Colombia and Brazil experience a similar quantity of total renewable water per inhabitant. However, there is a great difference in the conditions of these resources among these two countries. Taking into account the Table 1, it's seen that $34 \%$ of the waters of Brazil come from other countries, while in Colombia these correspond only to $1 \%$. Otherwise, the water quantity that leaves Brazil is $6 \%$, while in Colombia this value is $50 \%$. It can be highlighted from this analysis that Brazil has a middle level of water dependency, while Colombia can be considered a water producing country.

Brazil and Colombia, together with other six countries in South America, share one of the largest hydrographic basins in the world, the Amazon River basin, with a surface of approx. 7,050,000 $\mathrm{km}^{2}$, mostly covered by the Amazon Forest. Even that there are not solid legal bases that obligate countries to firm agreements for the integrated management and planning of the transboundary hydrographic basins, the good intentions showed in bilateral or multilateral agreements between the two countries are the most concrete evidence, which many times don't have the binding effect with the state policies (DOUROJEANNI, 2010). Amazon Basin is a common point of interest to eight South-American countries whose sovereign limits are overlapped regarding to it. Thus, this eight countries firmed, together, the Amazon Cooperation Treaty (TCA), a legal benchmark that instituted the Amazon Cooperation Treaty Organization (OTCA), in charge of the coordination of 
procedures and the dynamization of common decision execution taken by these countries in relation to the region.

Table 1 - Renewable water resources availability in Brazil and Colombia

\begin{tabular}{|c|c|c|}
\hline Country & Brazil & Colombia \\
\hline Population (inhabitants). & $180,654,000$ & $44,914,000$ \\
\hline Precipitation rate (mm/year) & 1800 & 2600 \\
\hline Volume TARHR $\left(\mathrm{km}^{2} /\right.$ year$)$ & 8233 & 2132 \\
\hline TARHR per capita $2000\left(\mathrm{~m}^{3} /\right.$ year $)$ & 48,314 & 50,635 \\
\hline TARHR per capita $2005\left(\mathrm{~m}^{3} /\right.$ year $)$ & 45,570 & 47,470 \\
\hline Superficial waters (\% TARHR) & 66 & 99 \\
\hline Subterranean waters (\% TARHR) & 23 & 24 \\
\hline Overlapping (\% TARHR) & 23 & 24 \\
\hline Waters that enter the country ( $\%$ TARHR) & 34 & 1 \\
\hline Waters that leave the country (\% TARHR) & 6 & 50 \\
\hline Total Use (\% TARHR) & 1 & 1 \\
\hline
\end{tabular}

Note: TARHR (Current Total of Renewable Water Resources); it reflects the available water resources, in theory, for the development proceeding from every source in the country.

Source: UNESCO (2008).

The creation of a common structure by these countries gains special relevance when is taken into account that the hydrographic basin has been adopted in the world, for a while, as a water resources management and planning unit. The natural flows do not obey the limits established by human societies, what draws us to the conclusion that activities developed in areas situated upstream of the boundary will significantly affect the quality and quantity of waters downstream this region. To interpret the river and its drainage basin as an integral unit results in the consideration that the artificial line draw to establish territories of different countries must play a role less significant in the integral management and planning of the transboundary waters. Thus, the elaboration of common forums of governability and governance is a challenge to neighboring countries, what would permit the suitable administration of transboundary hydrographic basins, assuring its integral conservation and preservation and avoiding the loss of resources.

Therefore, the celebration of local or regional agreements in transboundary areas requires the previous knowledge of the management systems of natural resources of the involved countries, the inventory of transboundary resources and the comparison of institutional and juridic benchmarks related to the management of water resources, making possible the prevention of conflicts and the optimization of equal distribution of gains for its respective populations.

\section{ENVIRONMENTAL AND WATER RESOURCES MANAGEMENT IN BRAZIL AND COLOMBIA}

\section{Environmental and water resources management systems in Brazil}

The Federal Act no. 6938, dated August 31, 1981, that deals with the National Environment Policy, was responsible for the institution of the National Environment System (SISNAMA), composed by Federal, State, Federal District and Municipal bodies and entities, as well as by foundations instituted by the Public Authority, responsible for the protection and the improvement of the environmental quality in Brazil. In terms of political and administrative organization, Brazil constitutes a federative republic that comprehends the Union, the 26 States, the Federal District and the 5565 Municipalities, all autonomous, as the Article 18 of the Federal Constitution of 1988 sets for. Thus, SISNAMA is, in fact and of right, a governmental political and administrative structure that constitutes the institutional framework of environmental management in Brazil. SISNAMA 
is constituted by the following bodies: Conselho de Governo [Government Council] (superior body), Conselho Nacional do Meio Ambiente [National Environment Council] (consultative and deliberative body), Ministério do Meio Ambiente [Environment Ministry] (central body), Instituto Brasileiro do Meio Ambiente e dos Recursos Naturais Renováveis [Environment and Renewable Natural Resources Brazilian Institute] (executive body), state bodies or entities (sectional bodies) and municipal bodies or entities (local bodies).

The Article 4th defined the instruments of the National Policy for the Environment, that include, among others, the establishment of environmental quality patterns; environmental zoning; environmental impacts assessment; licensing of activities that are effectively or potentially polluting; creation of protected areas; the national system of information regarding environment; compensatory or disciplinary penalties in not fulfilling the required measures to the preservation or correction of environmental degradation; and economic instruments, like forest concession, conservation easement, environmental insurance etc.

Even if it is important to recognize the multiple and significant advances already performed in Brazil in the environmental matter area, primarily from the promulgation of the National Environmental Policy and the implementation of the National Environment System, it is impossible not to highlight that one of the largest challenges to be faced by the country is the necessary integration between the environmental management system and the water resources management system. In fact, separation and poor integration between the two systems find their origins in the promulgation of the first relevant legal benchmark for the waters management in Brazil, Código de Águas [Waters Code], of 1934 (Federal Decree no. 24,643/1934). Besides being old and criticized for the incitation for the sectoral management of water, the Code was groundbreaking in establishing some concepts and instruments currently conceived as modern, such as water use charging (user pays principle; Article 36, paragraph 2nd), the polluter pays principle (Article 110), the right of water resources use grant (Article 43), the prioritized water use for public supply (Article 36) and the multiple waters use (Article 51, letter a). For that time, the Water Code established a very complex an modern water policy.

The Code was instituted in a moment where Brazil was performing the transition between a primary commodity exports economy and a urban-industrial economy, requiring an enhancement in hydroelectric energy production in order to supply and dynamize the industrialization process, reason why it can be stated that "despite of very advanced for that time, the Code led to a subordination of the water management to the interests of the electric energy sector, jeopardizing the integrated management of water resources" (MAGALHÃES JÚNIOR, 2007, p. 122).

The influence of global processes linked to environmental protection was reflected in a gradual and slow way in Brazil, specially in what concerns the worries about the water resources conservation and preservation in their quantitative and qualitative aspects. Re-democratization and awareness with respect the environmental degradation in the international scope significantly contributed to the increased relevance that the environmental matter had in the country coming from the state sphere. Thus, in the Federal Constitution of 1988, the environmental matter gains a specific chapter, based on the general principle that "everyone has the right to the ecologically balanced environment, a common use asset of people, and essential to healthy quality of life, remaining to the Public Authority and the collectivity the duty of defending it and preserving it for the current a future generations" (BRASIL, 1988).

The Federal Constitution of 1988 therefore reflected the environmental debate modernization in Brazil, stating that the environmental conservation is directly linked to the development process. The Constitution sets the legal basis of water management in Brazil, determining the legal regimen of watercourses and the administrative and legal competences of the federation units. Setti (2005, p. 151) believes that the Federal Constitution of 1988 elevated the water resources to a special care condition, as it can be understood from the number of articles that handle with the matter, highlighting the articles 20,21, 22, 23 e 26. Among these, article 22 stands out, attributing Union the 
competence of instituting a national water resources management system and defining the criteria of granting the rights of its use.

In a decade in which the debates about the need of a policy and a water management system were started in the country, the Constitution confirmed the water public domain in Brazil (federal and state waters) and established the hydrographic basin as a basal territorial unit for the water resources planning and management. This is an important aspect because, currently, one of the main instruments for the functionality of the Union domain rivers Hydrographic Basins Committees refers to the fact that, "in practice, the issue of the waters domainality has been constituted as an enormous challenge for the implementation of the water resources management in basins shared by the Union and the Federation units, and a great opportunity for the Federative Pact exercise" (MMA, 2006, p. 51).

In 1997 the Federal Act no. 9433 was promulgated, instituting the National Water Resources Policy and the National Water Resources Management System, organizing the planning sector and the water management in the country. The Federal Constitution of 1988 had already foreseen the Union competence for the creation of this system. Lei das Águas [Water Act], the name it became known by, reflected "the environmental and institutional crises derived from the irrational use history, water quality degradation and decrease of water supplies in the country" (MAGALHÃES JÚNIOR, 2007, p. 134). The paradigm of water offer continuous increase and environmental problems struggle based on palliative measures motivated the seek for water management modernization.

The National Water Resources Policy sets for, in its Article 3rd, some general guidelines for the implementation of the National Water Resources Policy, of which can be highlighted those lines concerning water resources management articulation with other sectors, specially environmental management, user sector, use of soil and the estuarine systems and coastal zones. Muñoz (2000, p. 17) states that these matters have not been sufficiently handled in the debate that aims to obtain subsidies for the regulation of the Federal Act no. 9433/1997 or to enhance the effective law; but also recognizes that they are essential for the success of the concrete implementation of the water resources policy because they are aspects said to be of horizontal coordination in the planning and management process.

The approach of integration between environmental and water resources management seems to be inevitable as long as the later constitutes environmental resources. Therefore it acknowledges the Federal Act no. 6938/1981 (National Environment Policy), by including among the environmental resources, in its Article 3rd, the atmosphere; the interior, superficial and subterranean waters; the estuaries; the territorial sea; the soil; the subsoil; the biosphere elements; the fauna and flora. Because of that, many understand that the water resources management should be part of the environmental management performed by SISNAMA. Nevertheless, this is not a generalized understanding. Nowadays, not rarely, but mostly in the common language, the environmental management is understood in a strict sense. Muñoz (2000, p. 18) emphasizes that the environmental management is practically identified with pollution control and fauna and flora protection; in this way, issues such as use conflict administration and water use charge would not be competence of SISNAMA.

Even taking into account that waters management process is recent in the country, what makes that many gains and additions may be recognized only in few years, many identify the absence of strategies, even future ones, for the implementation of a shared and integrated management of the common interests that rely on a hydrographic basin, as a result of economic, financial, technical and institutional limitations of the local representatives and of the conjunctural, social and fiscal instability of the country (GRISOTTO e PHILLIPPI JÚNIOR, 2003, p. 02).

The specialization of water resources management in an own system constitutes an advance. But it should be highlighted that the law, by anticipating the creation of hydrographic basin agencies as executive bodies of water resources policy, has permitted the institution of a body with similar competences to those of the municipalities, as the municipal territory management is responsibility of the later. In this way, it can be emphasized that "the posed challenge is to find mechanisms that 
allow for the action integration in environmental management with water resources management, taking into account that all the actions to be implemented for the improvement of the quantity and quality of water should be performed in the municipal territory" (FARIA, ROCHA E GOMES, 2007, p. 06).

\section{Environmental Management System in Colombia}

There is not an independent structure that manages water in an unified way in Colombia; however, it is possible to identify multiple rules that establish actions regarding this resource. It is possible to identify responsible persons and responsibilities, action levels, instruments and procedures that, acting together, allow for the visibility of the coherent structures related to national policies, even that they are not related among them. Water management in Colombia obeys environmental policies coming from the State, that develop themselves in rules of sectoral, vertical and descendent character, what is explained by the fact that the country organizes itself politically and administratively as an unitary republic, in which sovereignty is not divided, with a single center of authority that takes all the political decisions and has the monopoly of the applicable law rules elaboration throughout the territory and with respect to every citizen. The Political Constitution of 1991 indicated decentralization as a mechanism for regional development, but this is a process that advances and recedes with changes in government. It also recognizes a high fragmentation of institutionality due to continued transformations of institutional structures, which are a result of the current tendencies of State modernization, a fact that brings difficulties in providing cohesion to public management, whether vertically or horizontally.

The last two decades of the 20th century have brought strong political reforms to the country, that were recorded in the National Constitution of 1991. The different international agreements and conferences executed by the country direct the new way of acting in environmental management. There are approximately 60 articles in the Constitution that handle with natural resources and environmental matter, but the essential aspect lies on recognizing the right to a healthy environment as a collective right, establishing the ecological and social function of the property, and attributing to the State and the individuals the responsibility regarding National natural riches protection (MINAMBIENTE, CVC, 2002).

National Politics Constitution of 1991 defines the responsibilities of the State and the attributions of the different territorial beings. In general terms, the Constitution requires from the State the sustainability assurance of ecosystems and natural resources: It is State responsibility to protect the environment integrity and diversity, to conserve areas of special ecological importance and to foment the education needed for the achievement of these purposes (Article 79); the State will plan the management and the use of natural resources, in order to assure its sustainable development, conservation, restoration or replacement. In addition, it should prevent and control the environmental degradation factors, impose legal sanctions and require the reparation of damages caused. In the same way, it will cooperate with other nations in the sense of the protection of ecosystems placed in transboundary zones (Article 80); the general well-being and the improvement of the quality of life of the population are State social responsibilities. The solution of the non-fulfilled needs on health, education, environmental health and drinking water will be the essential objective of its activity (Article 366).

Although not being listed in the National Constitution of 1991, water in Colombia has always been considered a natural resource, but its relevance in conditions of potability is also notable, something necessary for social well-being (MINAMBIENTE, CVC, 2002). Because of the type of political and administrative organization of Colombian State, water is managed both in sectoral spheres and territorial spheres. Sectorally, its management primarily lies on the Ministry of Environment, Housing and Territorial Development (MAVDT), but the ministries of Social Insurance, Agriculture and Rural Development, among others, also have responsibilities. 
Based on the Article 80 of the National Constitution, the Law no. 99 of 1993 was promulgated, which organizes the environmental sector of the country and creates the National Environmental System (SINA), established from the management cycle based on coordinated tasks of knowing, planning, executing and assessing. SINA is conformed by the set of guidelines, rules, activities, resources, programs and institutions that permit the execution of general environmental principles contained in the Law no. 99/1993. Therefore, it was created a Ministry in charge of the formulation and direction of environmental policies based on scientific information, five research institutes that generate scientific knowledge, 34 sustainable development autonomous regional corporations (CARs) and four environmental units of the largest urban centers. Territorial entities of the country also take part of SINA, i.e. departments, districts, municipalities and ethnic groups territories that have functions of execution. (MINAMBIENTE, CVC, 2002). In addition, SINA incorporates state control institutions, such as National Control Authority. Contraloria General de la República (CGR) is the highest body of tax control in the State. As such, it has the obligation to provide the good use of public assets and resources and to contribute to the State modernization, pursuant to actions of continued improvement of distinct public entities. It could be stated that the most involved state structure in the water resources planning and management is the environmental sector.

In the national sphere, MAVDT is the body in charge of formulating the national environmental policy and defining the policies and regulations regarding recovery, conservation, ordinance, use, handling and improvement of national environment and natural resources. Because of this, it is the Ministry's responsibility to elaborate functions of regulation of the general character for restoration and recovery of natural resources, reduction of water resources pollution and conservation, preservation and handling of the environment. Besides, it is responsible for establishing the maximum permitted limits of emission, discharge, transport of substances, products, compounds or any other matter that can affect the environment or renewable natural resources; in the same way, it is its duty to prohibit, to restrict or to regulate the manufacture, distribution, use, disposition or reject of substances that cause environmental degradation (Article 5, number 25) or to determine the calculation factors and to fix the minimum tariff amount of use and improvement taxes of renewable natural resources (Article 5, numbers 29 and 30).

In the regional scope, the Regional Autonomous Corporations constitute the highest environmental authority in its jurisdiction area and also are the policies, plans, programs and rules (outlined by MAVDT) executors and, hence, are the responsible for the administration, sustainable use, improvement, protection, vigilance and control of renewable natural resources, water including; such activities must be performed in collaboration with territorial entities of its jurisdiction, i.e. departments, municipalities and indigenous territorial entities.

Law no. 99/1993 provides Corporations some functions of highest environmental authority in the area of its jurisdiction (Article 31, number 2). The same law also establishes that Corporations have a public character and are integrated by territorial entities that, by its characteristics, geographically constitute the same ecosystem or conform a geopolitical, biogeographic or hydrographic unit. They have administrative and financial authority, and own patrimony, constituting legal entities. They are in charge of the law of administering, within its jurisdiction, the environment and the renewable natural resources and fomenting its sustainable development (Article 23 of Law 99/1993). Currently they are not subject to or linked to the ministry, nor to any entity of national character; however, the financial autonomy depends on the assignment of resources that different members of the boards of directors grant them (PONCE, 2000).

Colombian territory divides its administration in Departments, Districts, Municipalities and Indian Territorial Entities, which have few degree of liberty with regards its territory management. Within these limits, territorial entities have the autonomy to self-governate by means of own authorities, to perform the due competences, to administer the resources and to establish the required tributes for the fulfillment of its functions and to participate in the national incomes (Articles 286 and 287 of the Political Constitution of Colombia). 
According to MIMABIENTE/CVC (2002, p. 108), the instruments of environmental management are defined "as multiple types of mechanisms that allow for guiding the actors in the operation of its activities targeted to the fulfillment of the National Environment System proposed objectives". As it does not exist an exclusive structure to manage water resources in the country, it is considered that the different instruments proposed for the environmental administration are the same to be used in the water resources management. The environmental management instruments used in Colombia are of many types: of command and control, based on rules that regulate the pair coercion-sanction; administrative, such as the environmental license; economic, based on the polluter pays principle; and of planning, such as the regional environmental management plans, hydrographic basins plans and municipal territorial ordinance plans.

The abundance of water in Colombia and the conflicts for its use impose an enormous challenge in the timepoint of establishing policies for its better use. Urban, industrial and agro-industrial development and the improvement of little and middle agriculture occur mainly in mountain ranges, right where the headwaters of almost all the main rivers of the country start, a fact that generate use conflicts and a strong pressure on water resources.

Otherwise Colombia, despite having rules that assure the citizens participation in the public life, is still far from incorporating them in the government processes. The development of a public institutional organization based on the congregation of the actors of consumption and production with water planning and management processes becomes urgent and necessary; as well as it is necessary to foment negotiation mechanisms between multiple water users in order to enter the process in a democratic way, before more organized sectors obtain advantages from the current water management system and its democratic conditions and reorientations imply more time, resources and social damage.

The situation becomes more difficult and complex in some cases in which it is verified that the government instances are deliberately supporting some particular private sector. For this reason, the creation or valorization of regulatory instruments and instances for multiple uses of water, based on the principles of democracy, decentralization and participation, being able to assure the satisfaction of rights of multiple users, prioritizing collective and public interests over private and individual ones. The instances and instruments should seek for the participation in distinct sectors of users and representatives from the nation, departments, municipalities and indigenous territorial entities, with marked presence in the civil society (BUITRAGO et al., 2010). The Box 1 shows the institutional structure of the environmental management system in Brazil and Colombia.

\section{Comparative analysis}

a) State political and administrative organization

The modern states organization permits the identification of a territorial action and authority distribution structure in at least three spatial scales: national, regional and local scale. The vertical distribution of authority and its ranges in different scales depend on each State political and administrative organization. In this sense, there might be centralized or decentralized States. A primary relevant difference between Brazil and Colombia resides in this aspect. Brazil is organized as a federative state, while Colombia organizes itself as a decentralized unitary state. This difference defines the competences and responsibilities that distinct territorial levels perform in almost all sectors of public administration. The Box 2 shows the distinct level of political and administrative organization of territory in each country.

Brazil has a specific and independent structure for water resources planning and management, while in Colombia such competences are put in the national environmental structure. In Brazil, the Federal Constitution of 1988 granted the Union the responsibility of instituting the National Water Resources Management System. The system corresponds to an institutional structure for the water 
resources management intended to be articulated to the National Environment System by means of a series of interfaces. In Colombia, nevertheless, water resources management specificities are diluted in environmental sector competences.

The difference in the political and administrative organization between the two countries has meaningful consequences. While Brazil experiences a federative political and administrative structure, Colombia is unitary, a fact that directly influences the decentralization levels of the decisions-making. In Brazil, the politic of participation calls the attention by the existence of different collegiate bodies in the distinct territorial and institutional levels. In Colombia, although there are lines in the National Constitution recognizing the participation as a democratic mechanism, in the territorial and institutional structure a strong degree of centralization of responsibilities and decision-making is clear.

\section{b) Water resources management institutional structure}

There is another relevant difference between the two countries concerning the specific issue of the water resources. The water resources management policies have different ranges for presenting different orders: in Brazil, they are State policies, while in Colombia they are government policies. For this reason, it is not rare that the government changes in Colombia result in a new orientation for the policies, with the common interests being delayed or even forgotten. In 2010, the National Water Resources Policy of Colombia was promulgated by President Álvaro Uribe Vélez, compliant to the National Development Plan (PND) 2006-2010 - "Estado Comunitario: Desarrollo para Todos" -, that in its Chapter 5 pointed out the need for "a risk and environmental management that promotes the sustainable development", incorporating the integral management of water resources as an action line. But, the Environment Ministry still has the competence of formulating the long term policies associated with the environment and other natural resources, a responsibility that also lies on the sphere of the government in course.

It is clear that there is a special interest for water resources planning and management in Brazil due to its fundamental role in urban and industrial development, while in Colombia the relative abundance of water resources (in a similar way regarding Brazil) and the energetic matrix of predominantly hydraulic origin have not constituted sufficient conditions to separate its management from environmental management.

Another essential difference concerns the participation in the decision-making. In the Brazilian water resource management system, the structure is composed by institutions with precise responsibilities and by deliberative and consultative bodies formed by State, civil society and users representatives. In this way, a structure with shared authority and decision-making together with the water management actors is formed.

In Colombia, there are collegiate bodies created by Law no. 99/1993 with direction and administration functions within the institutional structure of some environmental entities, but with restricted functions. The Corporate Assembly and the Regional Autonomous Corporations' Board of Directors are examples, with the environmental authority making the decisions in compliance with the established rules, without consulting users and communities. In Colombia, community participation in many times has only an informative character.

In Brazil, the regional level competences are responsibility of the State Secretariats, but also of the hydrographic basins committees. Nevertheless, the Secretariats responsibilities in the state sphere are similar to the Union competences in the national sphere, while the hydrographic basin committees constitute collegiate bodies that act in the rivers hydrographic basins according to their domainality (Union domain rivers or state rivers). In Colombia, acting in the regional sphere is a competence of the Regional Autonomous Corporation, Environment Administrative Departments of cities with more than a million of inhabitants, and Sustainable Development Corporations. In 
RIBEIRO, C. R.; BERMUDEZ, O. B.; LEAL, A. C.

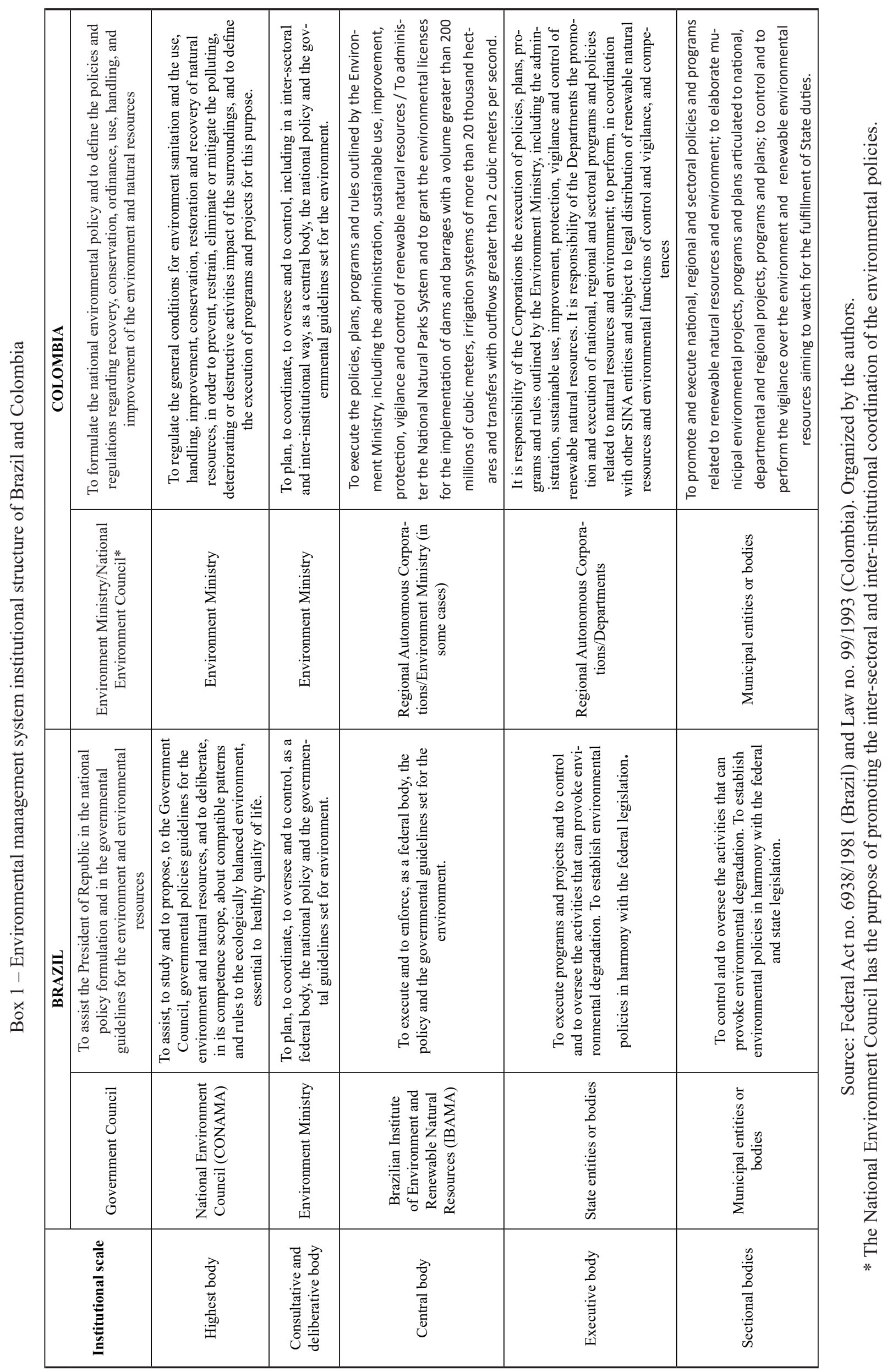


Box 2 - Distinct levels of political and administrative organization of the territory in Brazil and

\begin{tabular}{|c|c|c|}
\hline \multicolumn{2}{|c|}{ Colombia } \\
\hline Territorial Scale & Brazil & Colombia \\
\hline National & Union & Unitary State \\
\hline Regional & States and Federal District & Departments \\
\hline Local & Municipalities & Municipalities, Districts and Indigenous Territories \\
\hline
\end{tabular}

the highest level of CARs organogram there are corporate assemblies with the following responsibilities: a. To elect the Board of Directors; $b$. To assign the fiscal reviewer or the internal auditor of the Corporation; c. To know and to approve the administration management report; $d$. To know and to approve the profit and loss accounts of each annual period; e. To adopt the Corporation charters and the reforms introduced to it.

The CARs' Boards of Directors functions are as follows: a. To propose to the Corporate Assembly the adoption of the charters and its reforms; $b$. To determine the personnel of the Corporation; c. To allow for the participation of the Corporation in the constitution and organization of societies or associations and foundations or the admission in the already existing ones; $d$. To arrange the contracting of external credits; e. To determine the Corporation internal structure; to this purpose, it may create, suppress and fuse facilities, and may grant responsibilities according to the law; f. To approve the incorporation and the subtraction of protected areas; g. To authorize the entity functions delegation; $h$. To approve the general plan of activities and the annual budget of investments; i. To name of to remove, in compliance with the charters, the Chief Executive Officer of the Corporation. The Box 3 shows the institutional structure of the water resources management of Brazil and Colombia.

\section{c) Instruments of water resources and environmental management}

The water resources policy specificity in Brazil results in specific management instruments for it. These management instruments are, in theory, strongly inter-dependent and supplemental from the conceptual point of view, and have the objective of promoting the protection and recovering of water in a hydrographic basin whose physical expression is the set of investments to be performed there (PEREIRA, 2002). The implementation of these management instruments has demanded technical, political and institutional abilities and requires participation and acceptance by the actors involved, a fact that has limited its development and success.

In Colombian, management instruments of command and control type have been created in order to prevent the water bodies contamination and to determine the payment for use of the resource. The command and control policies implementation have, nevertheless, incurred high social costs, as the permissible limits of polluters cannot be accomplished by all polluting companies. In addition, the lack of monitoring of the control mechanisms for the fulfillment of the rule prevents the efficacy in the polluter emissions reduction and primarily determines a low level o compromise from the polluting agents (GARCIA, 2009). The Box 4 presents the water resources management instruments adopted in Brazil and Colombia, and the Box 5 presents the water resources management instruments classification adopted in both countries according to their typology. 
RIBEIRO, C. R.; BERMUDEZ, O. B.; LEAL, A. C.

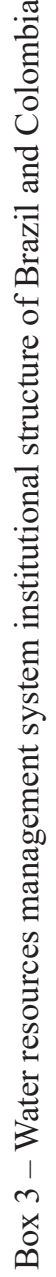

\begin{tabular}{|c|c|c|c|c|c|c|c|}
\hline \multirow[t]{2}{*}{$\begin{array}{l}\mathbb{x} \\
\text { put } \\
0 \\
0 \\
0\end{array}$} & 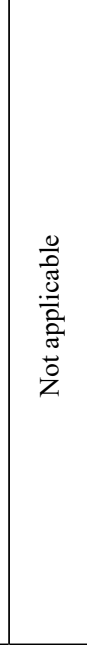 & 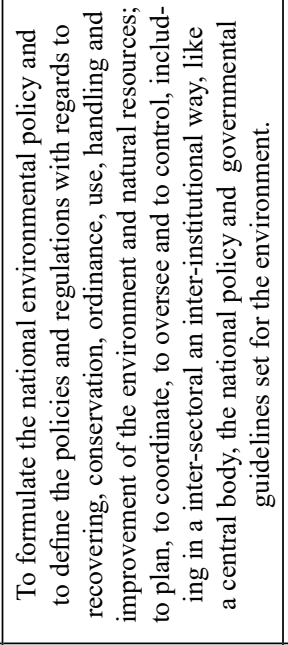 & 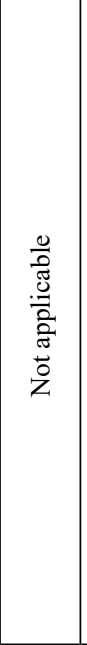 & 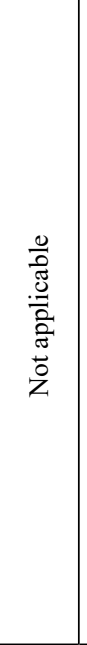 & 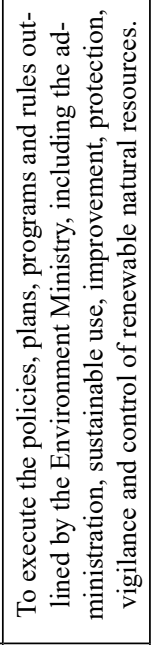 & 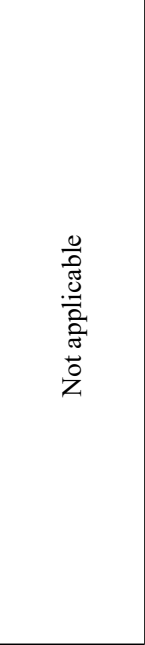 & 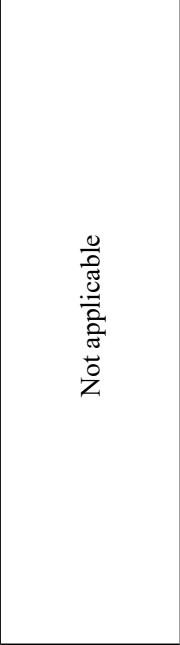 \\
\hline & 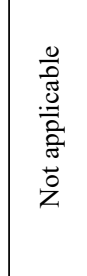 & 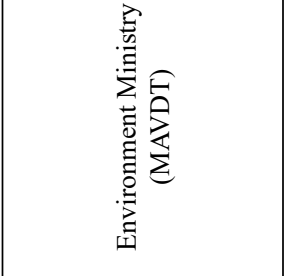 & 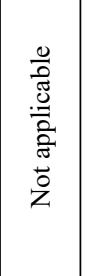 & 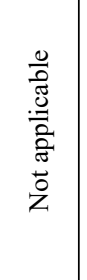 & 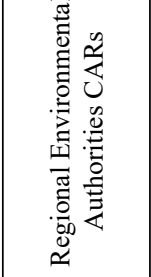 & 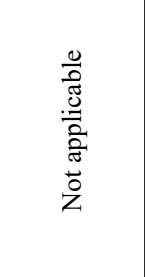 & 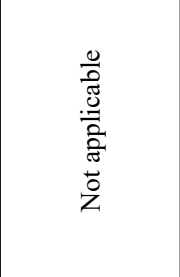 \\
\hline \multirow[t]{2}{*}{$\begin{array}{l}\overrightarrow{\bar{N}} \\
\frac{\Delta}{\Delta}\end{array}$} & 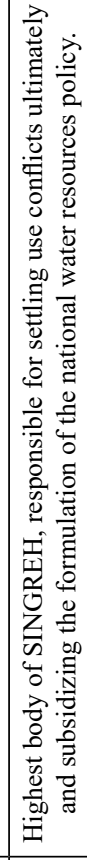 & 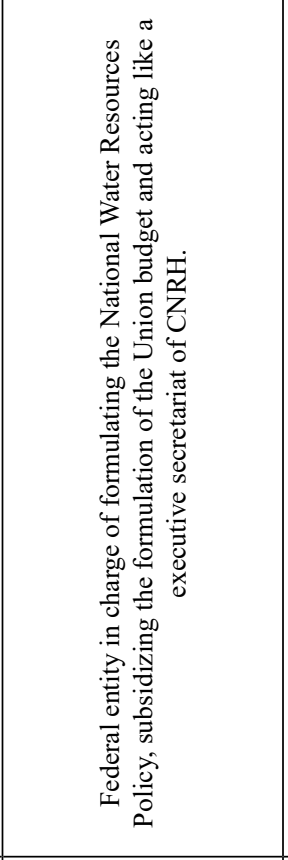 & 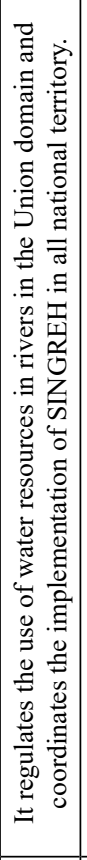 & 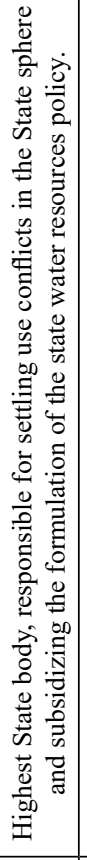 & 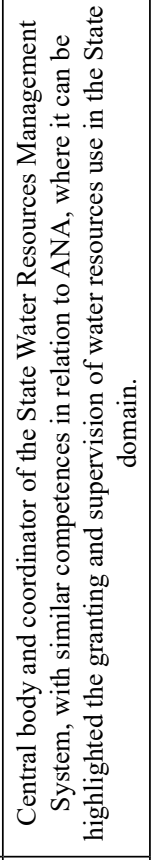 & 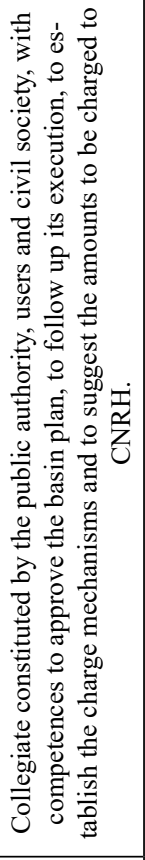 & 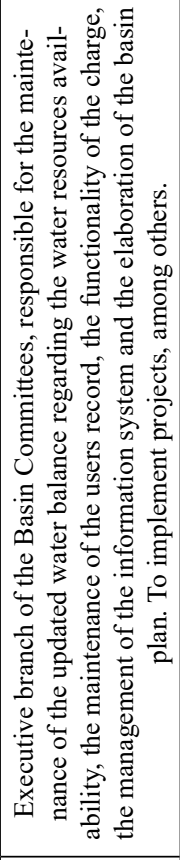 \\
\hline & 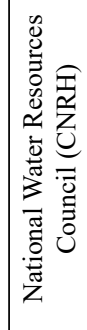 & 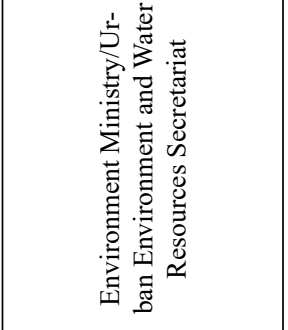 & 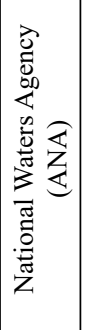 & 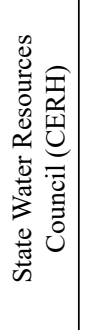 & 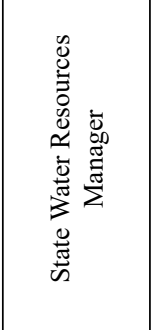 & 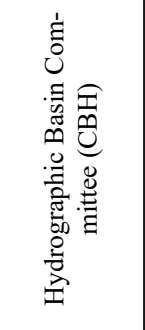 & 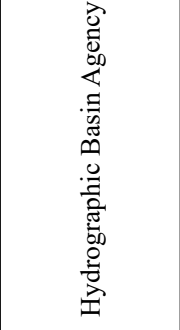 \\
\hline 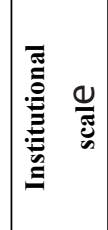 & 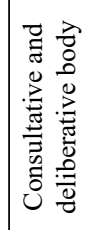 & 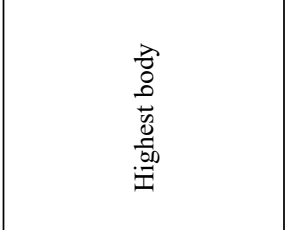 & 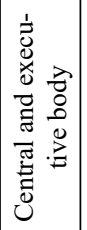 & 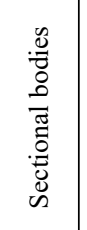 & 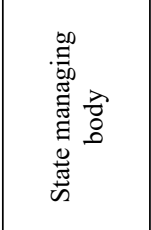 & 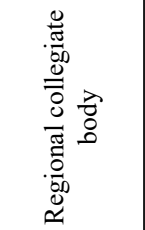 & 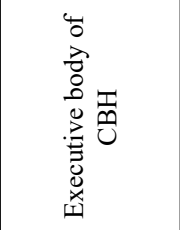 \\
\hline
\end{tabular}




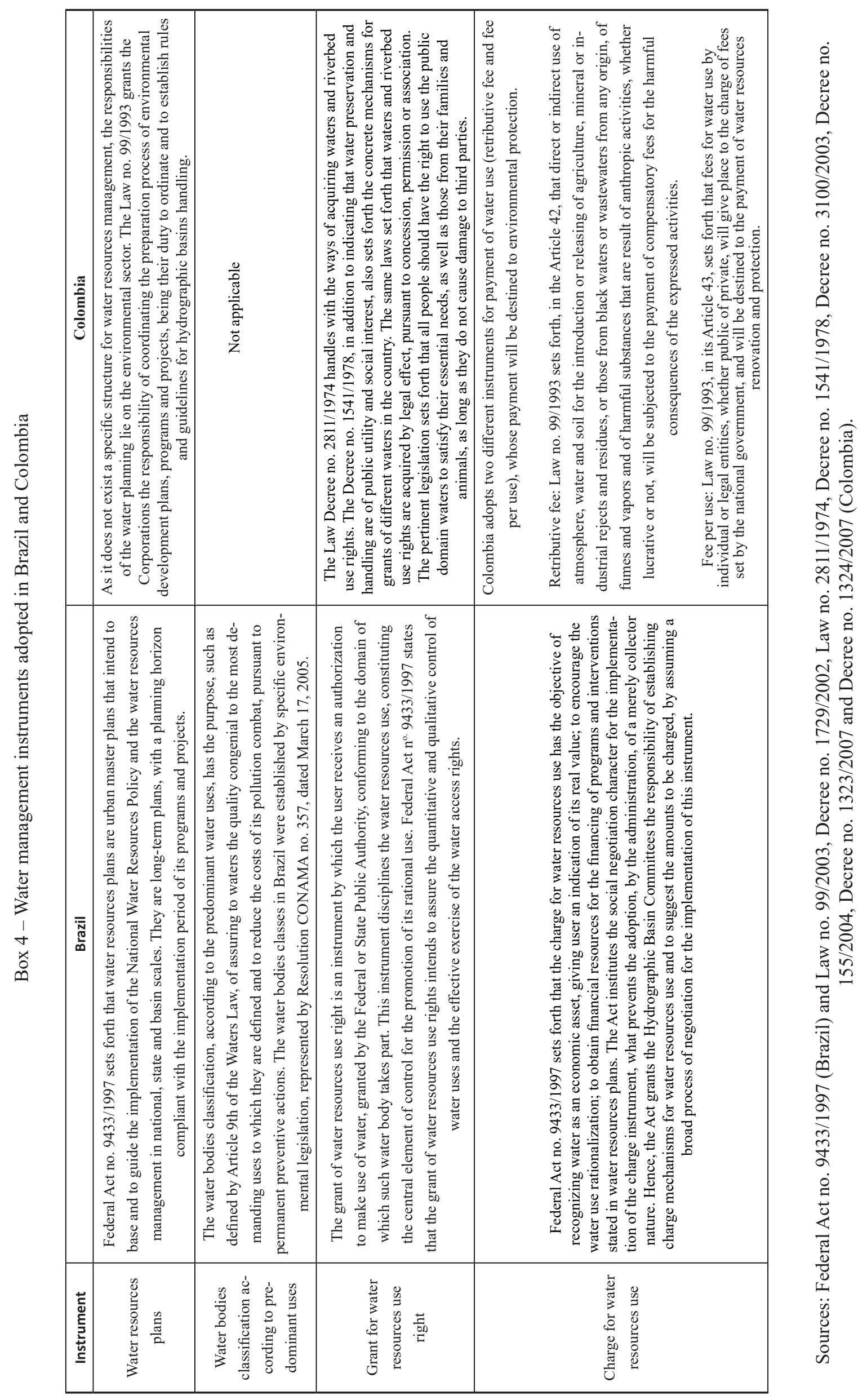


Box 5 - Water resources and environmental management instruments adopted in Brazil and Colombia according to their typology

\begin{tabular}{|c|c|c|}
\hline Typology & Brazil & Colombia \\
\hline \multirow{8}{*}{$\begin{array}{l}\text { Territorial ordi- } \\
\text { nance }\end{array}$} & Municipal urban master plan & Municipal territorial ordinance plan \\
\hline & Hydrographic basin plan & $\begin{array}{l}\text { Hydrographic basin handling and ordinance plan } \\
\text { Prioritizing hydrographic basins }\end{array}$ \\
\hline & Hydrographic micro-basin plan & Not applicable \\
\hline & Urban forest master plan & Forest zoning \\
\hline & Regional environmental zoning & Regional environmental management plan \\
\hline & Municipal environmental zoning & Not applicable \\
\hline & $\begin{array}{l}\text { Conservation units: integral protection units and sus- } \\
\text { tainable use units }\end{array}$ & $\begin{array}{l}\text { Special handling areas: reserve forest zones; natural parks } \\
\text { system areas; protection, study and savage fauna propaga- } \\
\text { tion zones; natural resources integrated handling districts; } \\
\text { hydrobiological species integrated handling areas; land- } \\
\text { scape preservation zones; soils conservation districts }\end{array}$ \\
\hline & $\begin{array}{l}\text { Other legally protected areas: permanent preservation } \\
\text { area, 'legal reserve' and fountainhead protection area }\end{array}$ & $\begin{array}{l}\text { Reserve forest zone (protective forest zones): headwater } \\
\text { streams of small water courses; margins and hillsides with } \\
\text { declivities higher than } 40 \% \text {; strips with } 50 \text { m of width on } \\
\text { the margins of fountainheads, watercourses and water } \\
\text { deposits; spaces for basin protection, dams and channels; } \\
\text { ways of communication }\end{array}$ \\
\hline \multirow{5}{*}{$\begin{array}{l}\text { Command and } \\
\text { control }\end{array}$} & Environmental licensing & Environmental licensing \\
\hline & $\begin{array}{l}\text { Environmental supervision: IBAMA and Instituto Chico } \\
\text { Mendes }\end{array}$ & $\begin{array}{l}\text { Environmental supervision: Accountability Office of Re- } \\
\text { public and Attorney General's Office of Republic }\end{array}$ \\
\hline & Water use granting & Water concessions \\
\hline & Water use charge & Fee per use and retributive fee \\
\hline & Environmental compensation & $\begin{array}{l}\text { Environmental compensation linked to environmental li- } \\
\text { censing }\end{array}$ \\
\hline \multirow{5}{*}{ Decision-making } & Water bodies classification & Not applicable \\
\hline & Environmental monitoring & Environmental monitoring \\
\hline & $\begin{array}{l}\text { Water resources and environmental information sys- } \\
\text { tems }\end{array}$ & Environmental information systems \\
\hline & Environmental education & Environmental education \\
\hline & $\begin{array}{l}\text { Environmental decision instances: } \\
\text { CONAMA, CNRH and } \mathrm{CBHs}\end{array}$ & $\begin{array}{l}\text { Environmental decision instances: National Environment } \\
\text { Council }\end{array}$ \\
\hline \multirow{5}{*}{ Economics } & Forest certification & Voluntary forest certification \\
\hline & Clean Development Mechanism & Clean Development Mechanism \\
\hline & Environmental insurance & Not applicable \\
\hline & Ecologic ICMS & Not applicable \\
\hline & Water production subside & $\begin{array}{l}\text { Certificate of forest incentive and 'forest keeper' [guarda- } \\
\text { bosques] families }\end{array}$ \\
\hline
\end{tabular}

Sources: Braga (2009, p. 15) and Ministerio del Medio Ambiente (2002). 


\section{ADVANCES IN TRANSBOUNDARY WATER RESOURCES SHARED MANAGEMENT OF BRAZIL AND COLOMBIA}

The interest of world countries in relation to transboundary water resources management, expressed through the large number of international conferences, forums and agreements handling this matter demonstrates the lack of regulation in a global scale. The development of an institutional and juridic apparatus for the regulation of the water resources use in a international scale is one of the biggest challenges to be faced by countries that share waters, because it meets the countries sovereignty and the prevalence of national legislation concerning the water use (RIBEIRO, 2008).

The primary agreement executed by Brazil and Colombia about the Amazon matter is the Amazon Cooperation Treaty (TCA), subscribed in July 03, 1978 by both countries and also by Bolivia, Ecuador, Guiana, Peru, Suriname and Venezuela. This treaty is the juridic instrument that recognizes the transboundary character of Amazon. From the legal benchmark established by TCA it was created, in December 14, 1998, the Amazon Cooperation Treaty Organization (OTCA), that constitutes an international organization that coordinates, by means of its Permanent Secretariat (inaugurated in Brasilia, in May 13, 2002), procedures and dynamizes the execution of its decisions. In 1995, amazon countries decided to institutionally empower the Amazon Cooperation Treaty (TCA) with the creation of a Permanent Secretariat with juridical personality. However, the decision was only implemented in 1998, with the Amendment Protocol to TCA approval that officially instituted the Amazon Cooperation Treaty Organization (OTCA) as a mechanism responsible for the improvement and strengthening of the cooperation process developed in the TCA sphere.

The Amazon Cooperation Treaty Organization (OTCA) has many action dimensions (political-diplomatic, strategic and technical dimension), that correspond to different instances of the Amazon Cooperation Treaty (TCA) and assure the fulfillment of purposes of the later, as well as of OTCA. One of its functions as a regional body is to coordinate itself together with other initiatives that figure in the territorial space that forms Amazon, whether in the infrastructure, transportation or communication matter. The Permanent Secretariat of OTCA is structured in five coordinations that contemplate different action areas of the organization, namely: Environmental Coordination, Science, Technology and Education Coordination, Health Coordination, Transport, Infrastructure, Communication and Tourism, and Indigenous Matters Coordination.

TCA reaffirms the amazon countries sovereignty, also aiming to stimulate, to institutionalize and to guide the regional cooperation process among them. The treaty foresees the scientific and technological research increment, information exchange, rational natural resources use, freedom of navigation, cultural patrimony preservation, healthcare management, creation of research sites, establishment of a proper infrastructure of communication and transportation and the increment of transboundary trading and tourism. Its central objective is the promotion of Amazon harmonic development and the incorporation of its territories to the respective national economies, seen as an essential element for the maintenance of balance between economic growth and environmental preservation. The Amazon Cooperation has a Strategic Agenda, approved by Foreign Relations Ministers in the Member Countries of OTCA in its 10th Meeting, that happened on November 2010, in Lima. The agenda adopted a horizon of eight years for its implementation after a broad consultation, regional sectoral dialogues and information gathering process in Member Countries that occurred in the sphere Strategic Plan 2004-2012 review.

The Article 5th of TCA is of special importance for the water resources area, by stating that, "taking into account the importance and multiplicity of functions that amazon rivers perform in the region's social and economic development process, The Contracting Parties will make every reasonable effort for the rational use of water resources".

OTCA also has an Annual Work Plan. The plan was elaborated based on the ongoing processes conclusions, previously consolidated activities and the priorities set in conversations with member countries authorities. The Annual Plan of 2011 adopted, for the Environment Coordination, the 
theme "Sustainable/Sustained Conservation and Use of Renewable Natural Resources". In the Water Resources sub-theme sphere, many awaited results were pointed, namely: I) To promote the adoption of an integrated and integral focus of water resources management (adaptation to climate changes, soils, civil society participation); II) To promote actions that facilitate the equitable access, as wide as possible, to quality waters for combined civil society, with an emphasis in the vulnerable populations, indigenous people and tribal communities; III) To promote the discussion of particular problems of hydrographic basins handling in border areas; IV) To stimulate the participation of vulnerable populations, indigenous people and tribal communities in water resources debates.

The third set of awaited results should be highlighted, dealing exactly with the water resources shared management by amazon countries. This set establishes a series of planned activities for the year of 2011 that are gathered in Sub-project III.1, that handles with Pilot Projects in Water Resources Integral Management (MIRH) in the Amazon Basin. Among the multiple planned activities in this sub-project sphere, two of them stand out: iii.1.4) Joint handling of superficial and subterranean waters and iii.1.5) Joint use of superficial and subterranean water in the region of three borders (Brazil, Colombia and Peru). This last item comprises another sub-item: iii.1.5.1) Environmental, climate and social-economic characterization of the pilot area.

A fundamental aspect of TCA are the projects and programs to be implemented by member countries. By signing TCA, the eight member countries have committed to make efforts and joint actions to promote the harmonic development of their amazon territories, by means of conservation and rational use of natural resources with equitable and mutually useful results. Since the establishment of the Permanent Secretariat of OTCA in Brasilia, agreements were executed and programs and projects were implemented aiming to stimulate Amazon sustainable development. Therefore, OTCA is open to the technical and financial support of multilateral organisms and cooperative countries. The programs and projects are executed according to mandates and management instruments of the Permanent Secretariat of OTCA, attempting to guide its strategies and purposes in accordance with the intents established by member countries and the Strategic Plan 2004-2012.

In the water resources area, the Integrated and Sustainable Transboundary and Amazon River Basin Water Resources Management Project considering Climatic Changes and Variability, known as 'GEF Amazonas', can be emphasized. The project intends to develop a consensual vision of sustainable development for the region, with the purpose of elaborating and executing an Action Strategic Plan (PEA) for Amazon Basin and creating a favorable surrounding to its future application. The Action Strategic Plan is considered a key element to the success of sustainable use of water resources integrated management and to the promotion of the adaptation to climate changes, pursuant to the execution of a supporting activities program.

Piedra-Calderón $(2007$, p. 71) points out that the proposed dynamic for the Amazon region harmonic development would involve high costs that certainly could not be assumed by member countries in an individual manner. Thus, the OTCA's integration pattern is based on functional cooperation and fusion of decisions that span common interests. In this sense, OTCA contribution for South America integration should occur by means of consolidation of cooperation instruments between member countries related to Amazon sustainable development and management, something that can be made feasible from the implementation of common policies, plans, programs and projects. Here, 'GEF Amazonas' stands out, an initiative that targets the institutional strengthening, aiming to plan and to execute, in a coordinate way, sustainable handling and protection activities for Amazon water resources and soil. Through this project it is intended the provision of integrated solutions, e.g. the water matter in the region, something that gains special importance because of the existent interdependence between amazon countries owning a hydrographic system supplied, in great proportion, by waters that come from Andes Mountain Range (SERRANO, 2006, p. 90).

One of the most important results of TCA for Brazil and Colombia was the adoption of a bilateral agreement, known as Amazon Cooperation Treaty between the Government of the Fede- 
rative Republic of Brazil and the Government of the Republic of Colombia, celebrated in March 12, 1981. The main purpose of the agreement was stimulating the development of a cooperation dynamic for the performance of joint actions for the national experiences exchange in matters of regional development and scientific and technological investigation adapted to Amazon Region, willing to reach harmonic development of its respective amazon territories, in benefit of their populations and properly preserving the zone ecology (Article I). The agreement recognizes that rational exploration of amazon resources constitutes a valuable contribution in the constant efforts performed by both countries in the sense of raising the standard of living of their people through a progressive use of natural resources of Amazon Region. The agreement does not bring any specific disposition about environmental protection, conservation and/or preservation of water resources, limiting their commitments, in relation to this matter, to the use for river navigation.

Other important document firmed by the two countries is the Agreement for the Conservation of Fauna and Flora of Amazon Territories of the Republic of Colombia and Federative Republic of Brazil, celebrated by both countries in June 20,1973. The agreement, focusing the conservation of flora and fauna in the amazon territory from these countries, also brings some articles related to the water resources matter. Article I foresees the performance of researches, whether jointly or not, by these two countries, with the purpose of gathering basic data for the proper handling of renewable water resources of that territories, including pursuant to the establishment of biological reserves representative of different ecosystems and biogeographic unities. Yet, Article II sets forth that the countries should promote meetings with technicians, with the purpose of tracing guidelines as uniform as possible regarding multiple theme areas, of which fishing in interior waters is included.

Finally, other bilateral agreement celebrated between Brazil and Colombia related to water resources management is the Supplemental Covenant to the Basic Agreement of Technical Cooperation between the Government of the Federative Republic of Brazil and the Government of the Republic of Colombia about Technical, Scientific and Technological Cooperation in the Sanitation and Environmental Protection Field. The covenant was celebrated in September 02, 1981. In Brazil, the covenant became effective in February 27, 1986. In Colombia, the covenant received national approval through Law no. 27, dated January 31, 1986. The covenant establishes a series of joint measures for the cooperation between both countries in the sanitation and environmental field, directly linked to water resources management.

\section{FINAL CONSIDERATIONS}

Although Brazil and Colombia have already firmed three important bilateral agreements related, directly or indirectly, to water resources management, in practice, few advances were performed by both countries in transboundary waters shared management. Even recognizing the importance of these agreements in the consolidation of national legislations harmonization process, gradually eliminating limits of distinct juridic areas, specially with regards to water pollution, it cannot be ignored the fact that the shared management faces the States sovereignty issue, what makes the development of cooperation in many times a slow process, despite the already reached results throughout several years (POMPEU, 2006).

Azevedo and Sell (2006, 284-285) point out, in a commentary on the application of principles of the Water International Law in the Amazon Basin, that "in relation to water resources, the Amazon Cooperation Treaty discipline limited itself by assuring the freedom of navigation in amazon rivers and the (generic) prediction of natural resources rational use, with regards the prediction that the use and improvement of natural resources in the respective territories is an inherent right of the State, and its exercise shall not have restrictions other than those resulting from the International Law". Yet, Sant'Anna (2009, p. 178) emphasizes that "transboundary water resources management is still in the beginning, as this first phase of the OTCA project only had studies and reports as result". 
International agreements, whether bilateral or multilateral, following the approval of the competent authorities, integrate to the law of the signatory countries, conditioning national legislation. In many cases, countries pertaining to the same economic community assume the commitment of establishing similar legal rules, in special regarding water quality, in order to encumber the uses in an equal basis, without the benefit of users from a country against the other ones by less demanding laws. In this way, the geographical position of a country in relation to hydrographic basins placed in its territory, whether national or transboundary, reflects, equally, in the respective legislation, given that the occurrence of self-limitations to the own sovereignty and to the fact that waters represent a natural resource shared with neighbouring States.

If in the inner sphere of the States the complexity that evolves the rational use of water is enormous, in international nature enterprises, i.e. those that involve more than one sovereign State, the questions multiply. For that reason, it is indispensable the establishing of guiding rules for delimitation of rights and obligations of States in their respective domains, in such a way to conciliate, in the most harmonic way, the particular interests of each one of them with those from the remaining parties. This process, in order to become successful, should start from some principles applicable to water resources shared use among countries, extracted from Public International Law. Brazil and Colombia are two South-American countries that stand out for its significant water availability and for sharing waters of the Amazon Basin, considered the largest hydrographic basin in the world. Both countries produced some advances in their transboundary waters management from some bilateral agreements already established, a trajectory that begun with the execution of the Amazon Cooperation Treaty.

Nevertheless, even that some advances already can be registered, many challenges also appear. In order to advance in transboundary waters shared management, the knowledge of the specificities of the legal framework and institutional arrange of water resources management in the involved countries is necessary, identifying existing consistencies and divergences. Thus, even though the already set agreements open the possibility for water resources shared management, specially the Supplemental Covenant to the Basic Agreement of Technical Cooperation, that sets forth a series of commitments for joint cooperation in areas of environmental protection and sanitation, the following advances are still required: a) promoting the detailed diagnosis of superficial and subterranean waters that both countries share; b) diagnosing, monitoring and controlling economic activities impact performed upstream (Colombia) over the the quantity and quality of water downstream (Brazil); c) establishing mechanisms and instruments, whether economic or not, for the payment for environmental services provided by Colombia to Brazil, i.e. the production of shared water by the two countries; d) strengthening water resources and environmental management legal framework and institutional structure of the two countries and establishing guidelines and mechanisms for its compatibilization and integration, making possible the development of conjunct policies and programs targeting the sustainable management of shared waters; e) stimulating the constitution of collegiate bodies necessarily having the participation of all management actors (organized civil society, public authority and water users) and of all levels of authority (local, regional and national level) in an equitable form between the two countries, preventing decision-making asymmetries and; f) stimulating the consultation of representatives of associations related to water resources management of the countries that share their waters, aiming to incorporate different visions and perspectives in transboundary hydrographic basins planning, management and integral handling.

\section{REFERENCES}

AZEVEDO, C, V. J. do C.; SELL, M. S. Direito Internacional de Águas na Bacia Amazônica: aplicação regional de princípios do Direito Internacional de Águas. In: MENEZES, W. (Coord.). Estudos de Direito Internacional: Anais do IV Congresso Brasileiro de Direito Internacional. Curitiba: Juruá, 2006, vol. VI, p. 283-295. 
BRAGA, R. Instrumentos para a gestão ambiental e de recursos hídricos. Recife: Universidade Federal de Pernambuco, 2009.

BRAGA, B.; FLECHA, R.; PENA, D. S.; KELMAN, J. A reforma institucional do setor de recursos hídricos. In: BRAGA, B.; REBOUÇAS, A. da C.; TUNDISI, J. G. (Org.). Águas doces no Brasil: capital ecológico, uso e conservação. 3. a ed. São Paulo: Escrituras, 2006, p. 639-676.

BUITRAGO, N.; DI MAURO, C.; BUITRAGO, O. Potenciales conflictos por el uso del agua en la produción de flores en la region metropolitana de Bogotá. In: CONFERÊNCIA INTERNACIONAL DA REDE WATERLAT, 2, 2010, São Paulo. Anais... São Paulo: Waterlat, 2010, p. 01-19.

COSTA, R. H. P. G. Água: matéria-prima primordial à vida. In: TELLES, D. A.; COSTA, R. H. P. G. (Coord.). Reuso da água: conceitos teorias e práticas. São Paulo: Blücher, 2007.

DOUROJEANNI, A. Cuencas y acuiferos transfronterizos. Santiago: Fundación Chile, 2010.

FARIA, E. F. de; ROCHA, R. M. L.; GOMES, I. M. Os desafios da integração da gestão ambiental com a gestão de recursos hídricos. In: CONGRESO NACIONAL DO CONPEDI, XVI, 2007, Belo Horizonte. Anais... Florianópolis: Fundação Boiteux, 2007, vol.1, p. 4.275-4.293.

GARCIA, M. Análisis de la efectividad de las tasas retributivas en Colombia: estudio de caso. 2009. 76 f. Monografia (Graduação em Economia) - Pontifícia Universidad Javeriana, Bogotá, 2009.

GRISOTTO, L. E. G.; PHILIPPI JÚNIOR, A. Desafios para a integração de políticas e instrumentos setoriais ao sistema de gestão de recursos hídricos no Estado de São Paulo. In: SIMPÓSIO BRASILEIRO DE RECURSOS HÍDRICOS, XV, 2003, Curitiba. Anais... Curitiba: Associação Brasileira de Recursos Hídricos, 2003, v.1, p. 1-20.

MAGALHÃES JÚNIOR, A. P. Indicadores ambientais e recursos hídricos: realidade e perspectivas para o Brasil a partir da experiência francesa. Rio de Janeiro: Bertrand Brasil, 2007.

MARGAT, J. Repartition des ressources et des utilisations d'eau dans le monde: disparités présentes et futures.La Houille Blanche, Paris, n. ${ }^{\circ}$ 2, 1998, p. 40-51.

MINISTERIO DEL MEDIO AMBIENTE. CORPORACIÓN AUTÓNOMA REGIONAL DEL VALLE DEL CAUCA. Las voces del SINA. Bogotá: MMA/CAR del Valle del Cauca, 2002.

MINISTERIO DEL MEDIO AMBIENTE. Lineamientos de Política para el Manejo Integral del Agua. Bogotá: MMA, 2003.

MINISTERIO DEL MEDIO AMBIENTE. INSTITUTO DE HIDROLOGIA, METEOROLOGIA Y ESTUDIOS AMBIENTALES. Informe anual sobre el estado del medio ambiente y los recursos naturales renovables en Colombia. Bogotá: MMA/IDEAM, 2004.

MINISTERIO DEL AMBIENTE, VIVIENDA Y DESARROLlO TERRITORIAL. Política Nacional para la Gestión Integral del Recurso Hídrico. Bogotá: Ministerio del Ambiente, Vivienda y Desarrollo Territorial, 2010.

MINISTÉRIO DO MEIO AMBIENTE. Plano Nacional de Recursos Hídricos: panorama e estado dos recursos hídricos do Brasil. Brasília: Ministério do Meio Ambiente, 2006.

MUÑOZ, H. R. Razões para um debate sobre as interfaces da gestão dos recursos hídricos no contexto da Lei de Águas de 1997. In: MUÑOZ, H. R. (Org.). Interfaces da gestão de recursos hídricos: desafios da Lei de Águas de 1997. 2.a ed. Brasília: Secretaria de Recursos Hídricos do Ministério do Meio Ambiente, 2000, p. 13-30.

ORGANIZACIÓN DE LAS NACIONES UNIDAS PARA LA EDUCACIÓN, LA CIENCIA Y LA CULTURA. Agua para todos, agua para la vida: Informe de las Naciones Unidas sobre el desarrollo de los recursos hídricos en el mundo. Paris: Organización de las Naciones Unidas para la Educación, la Ciencia y la Cultura, 2004.

ORGANIZACIÓN DE LAS NACIONES UNIDAS PARA LA EDUCACIÓN, LA CIENCIA Y LA CULTURA. El agua, una responsabilidad compartida: $2 .^{\circ}$ Informe de las Naciones Unidas sobre el desarrollo de los recursos hídricos en el mundo. Zaragoza: Sociedad Estatal Expoagua Zaragoza, 2008.

PEREIRA, J. S. A cobrança pelo uso da água como instrumento de gestão dos recursos hídricos: da experiência francesa à prática brasileira. 2002. 364 f. Tese (Doutorado em Engenharia) - Instituto de Pesquisas Hidráulicas, Universidade Federal do Rio Grande do Sul, Porto Alegre, 2002. 
PIEDRA-CALDERÓN, A. F. A Organização do Tratado de Cooperação Amazônica e a consolidação do processo de integração sul-americana. 2007. 118 f. Dissertação (Mestrado em Ciência Política) - Instituto de Filosofia e Ciências Humanas, Universidade Federal do Rio Grande do Sul, Porto Alegre, 2007.

POMPEU, C. T. Direito de águas no Brasil. São Paulo: Revista dos Tribunais, 2006.

RIBEIRO, W. C. Geografia política da água. São Paulo: Annablume, 2008.

SANT'ANNA, F. M. Cooperação internacional e gestão transfronteiriça da água na Amazônia. 2009. 197 f. Dissertação (Mestrado em Geografia Humana) - Faculdade de Filosofia, Letras e Ciências Humanas, Universidade de São Paulo, São Paulo, 2009.

SERRANO, R. A. A Organização do Tratado de Cooperação Amazônica (OTCA): um desafio permanente. In: Diplomacia, Estratégia e Política. Brasília, 2006, n. ${ }^{\circ}$ 4, abr.jun., p. 86-100.

SETTI, A. A. Legislação para uso dos recursos hídricos. In: PRUSKI, F. F.; SILVA, D. D. da. (Org.). Gestão de recursos hídricos: aspectos legais, econômicos, administrativos e sociais. Brasília: Associação Brasileira de Recursos Hídricos/Universidade Federal de Viçosa, 2005, p. 121-412.

Submitted july 2015 Accepted august 2015 